ISSN. 2775-4324 (Online)

Journal of Physical Activity and Sports

Volume 2, Nomor 3, Bulan 2021, 356-367

Journal of Physical Activity and Sports

\title{
Pola Pembinaan Prestasi Olahraga Beladiri Wushu Koni Kabupaten Semarang Di Masa Pandemi Covid 19
}

\author{
Gandung Dwi Nurwanda ${ }^{1 *}$, Utvi Hinda Zhannisa ${ }^{2}$, Danang Aji Setyawan ${ }^{3}$ \\ ${ }^{123}$ Universitas PGRI Semarang. Jalan Sidodadi Timur Nomor 24 - Dr. Cipto, Karangtempel, Semarang \\ Timur, Kota Semarang, Jawa Tengah, 50232, Indonesia. \\ gandung130498@gmail.com
}

Received: 4 Juni 2021; Accepted: 29 Desember 2021

\begin{abstract}
The purpose of this study is to describe the pattern of fostering the sports achievement of wushu martial arts in the KONI Kabupaten Semarang during the Covid 19 pandemic. This study uses descriptive qualitative methods. Sources of data in this study consisted of athletes, coaches, and administrators of the KONI Kabupaten Semarang. The data collection technique is an interview technique. The data analysis technique used an interactive analysis model. The results showed that the pattern of fostering the sports achievement of the KONI Kabupaten Semarang uses a talent scouting system, which means the process of scouting the talents of athletes from the recruitment stage to the final stage of coaching. The spirit of training and the athletes' efforts to achieve optimal performance are supported by the quality of the coaches which are already good, because all coaches have coach certification, and the training programs provided are in the good category. The management organization in good criteria is seen from the attention of the administrators to the athletes, and the management of Wushu martial arts. The facilities and infrastructure owned are included in the criteria both in terms of the completeness and quality of the existing facilities and infrastructure. Funding for the implementation of Wushu martial arts performance coaching is included in the criteria both seen from the source of funding and how to allocate funds for the coaching process. The conclusion obtained is that the pattern of fostering wushu martial sports achievements at the KONI Kabupaten Semarang is running well, has been programmed, tiered, and sustainable.
\end{abstract}

Keywords: pattern of development, achievement, wushu martial arts

\begin{abstract}
Abstrak
Tujuan penelitian ini untuk mendeskripsikan pola pembinaan prestasi olahraga beladiri wushu KONI Kabupaten Semarang di masa pandemi Covid 19. Penelitian ini menggunakan metode kualitatif deskriptif. Sumber data dalam penelitian ini terdiri atlet, pelatih, dan pengurus KONI Kabupaten Semarang. Teknik pengumpulan data adalah teknik wawancara. Teknik analisis data menggunakan model analisis interaktif. Hasil penelitian menunjukkan bahwa pola pembinaan prestasi olahraga beladiri wushu KONI Kabupaten Semarang menggunakan sistem talent scouting maksudnya proses pemanduan bakat atlet dari mulai tahap perekrutan sampai tahap akhir pelaksanaan pembinaan. Semangat berlatih dan usaha atlet dalam mencapai prestasi yang optimal ditunjang oleh kualitas pelatih sudah baik, karena semua pelatih memiliki sertifikasi pelatih, dan program latihan yang diberikan termasuk dalam kategori sudah baik. Organisasi kepengurusan dalam kriteria baik dilihat dari perhatian pengurus kepada atletnya, dan manajemen kepengurusan beladiri Wushu. Sarana dan prasarana yang dimiliki termasuk dalam kriteria baik dilihat dari kelengkapan dan kualitas sarana dan prasarana yang ada. Pendanaan untuk pelaksanaan pembinaan prestasi olahraga beladiri Wushu termasuk dalam kriteria baik dilihat dari sumber pendanaan dan cara mengalokasi dana untuk proses pembinaan. Simpulan yang diperoleh adalah pola pembinaan prestasi olahraga beladiri wushu di KONI Kabupaten Semarang berjalan dengan baik, telah terprogram, berjenjang, dan berkesinambungan.
\end{abstract}

Kata kunci: Pola pembinaan, prestasi, olahraga beladiri wushu 


\section{PENDAHULUAN}

Olahraga merupakan suatu fenomena yang mendunia dan menjadi bagian yang tidak terpisahkan dalam kehidupan sehari-hari, sehingga olahraga menjadi sarana strategis untuk membangun kepercayaan diri, identitas bangsa, dan kebanggaan nasional. Berbagai kemajuan pembangunan di bidang keolahragaan yang bermuara pada meningkatnya budaya dan prestasi olahraga. Melalui pembinaan olahraga yang sistematis, kualitas sumber daya manusia dapat diarahkan pada peningkatan pengendalian diri, tanggung jawab, disiplin, sportivitas yang pada akhirnya dapat memperoleh prestasi olahraga yang dapat membangkitkan kebanggaan nasional. Oleh sebab itu, pembangunan olahraga perlu mendapatkan perhatian yang lebih proporsional melalui pembinaan, manajemen, perencanaan dan pelaksanaan yang sistematis dalam pembangunan nasional.

Prestasi di bidang olahraga dapat mengangkat nama baik klub olahraga, sekolah, daerah serta mengharumkan nama bangsa dan negara di dunia. Persaingan olahraga prestasi dewasa ini semakin ketat. Prestasi bukan lagi milik perorangan, tetapi sudah menyangkut harkat dan martabat suatu bangsa. Itulah sebabnya berbagai daya dan upaya dilakukan oleh suatu sekolah atau daerah, maupun negara untuk menempatkan atletnya sebagai juara di kegiatan-kegiatan olahraga.

Pembinaan olahraga merupakan sebuah tahap penting dalam mencapai prestasi olahraga. Namun banyak klub-klub olahraga yang kurang memperhatikan hal ini, sehingga tidak dapat bersaing dalam hal prestasi maupun keberlangsungan latihan tidak terencana dengan baik, sistematis dan bertahan lama. Sistem pembinaan prestasi olahraga di Indonesia adalah pemanduan bakat dan pengembangan bakat. Jadi, untuk mencapai jenjang prestasi tinggi di butuhkan sistem pembinaan yang baik. Tanpa pembinaan yang tersistem dengan maksimal maka tahap pencapaian prestasi tidak akan tercapai.

Pembinaan olahraga merupakan bagian dan upaya peningkatan kualitas manusia Indonesia yang ditujukan pada peningkatan kesehatan jasmani dan rohani seluruh masyarakat, serta pengembangan prestasi olahraga yang dapat membangkitkan rasa kebanggaan nasional. Pada saat ini pembinaan olahraga kurang diperhatikan, sehingga perlu ditingkatkan pendidikan jasmani dan pembinaan olahraga di lingkungan sekolah maupun masyarakat agar mendapatkan prestasi sesuai dengan target. Pembinaan prestasi olahraga merupakan tanggung jawab Komite Olahraga Nasional Indonesia (KONI).

KONI adalah wadah organisasi olahraga nasional mempunyai tanggung jawab yang besar terhadap pembinaan prestasi olahraga di Indonesia. Konsep pembinaan atlet untuk dapat mencapai prestasi yang tinggi dan maksimal harus dilakukan secara berjenjang dan berkelanjutan hingga prestasi puncak. Mencapai prestasi puncak pembinaan peserta didik tidak bisa dilakukan sendirisendiri, namun harus secara sistemik. 
Menurut Danardono (2012), keberhasilan pembinaan prestasi atlet yang sistemik, terpadu, terarah dan terprogram dengan jelas dilihat dari beberapa faktor yang mempengaruhi, yaitu: (1) Tersedianya atlet potensial (Talented Athletes) yang mencukupi, (2) Tersedianya pelatih profesional dan dapat menerapkan IPTEK, (3) Tersedianya sarana prasarana dan kelengkapan olahraga yang memadai, (4) Adanya program yang berjenjang dan berkelanjutan, ditunjang dengan adanya anggaran yang mencukupi dan hubungan yang baik antara semua pihak (atlet, pelatih, pembina, pengurus, Pengprov, KONI, dan Pemerintah), dan (5) Perlu diadakannya tes dan pengukuran kondisi atlet secara periodik.

Perkembangan olahraga perlu diperhatikan adanya upaya peningkatan kualitas manusia. Sebagai suatu bangsa dalam aspek kehidupan perlu dilaksanakan pembinaan secara sungguh-sungguh, sehingga memungkinkan untuk memberi sumbangan nyata dalam pembangunan nasional. Peningkatan kemajuan dalam bidang olahraga harus diimbangi dengan peningkatan sumber daya manusia. Melalui upaya dan pembinaan serta pengembangan olahraga, karena itu olahraga yang mempunyai peranan dalam pembangunan nasional perlu dibina dan dikembangkan tentunya harus mempunyai sistem yang jelas.

Pembinaan dan pembibitan olahraga merupakan permasalahan penting yang harus mendapat perhatian. Pembinaan dan pengembangan olahraga yang merupakan bagian upaya peningkatan kualitas manusia Indonesia diarahkan pada peningkatan jasmani, mental dan rohani masyarakat, serta ditujukan untuk pembentukan watak dan kepribadian, disiplin dan sportifitas tinggi serta peningkatan prestasi yang dapat membangkitkan rasa kebanggaan nasional.

Selanjutnya upaya peningkatan prestasi olahraga, perlu terus dilaksanakan pembinaan olahragawan melalui pencarian dan pemanduan bakat, pembibitan, pendidikan dan pelatihan olahraga prestasi yang didasarkan pada ilmu pengetahuan dan teknologi secara lebih efektif dan efisien serta peningkatan kualitas olahraga baik tingkat pusat maupun daerah.

Perlunya pembinaan olahraga menjamin keberhasilan suatu negara dalam membawa prestasi dan nama harum bangsa. Pembinaan olahraga haruslah terjalin dalam suatu sistem yang saling terkait seperti mata rantai yang tak terputus dari yang paling dasar hingga pembinaan yang tertinggi. Potensi yang ada terus menerus dapat dibina, dipelihara dan dikembangkan dari waktu ke waktu sehingga tidak tertutup kemungkinan potensi tersebut menjadi pribadi-pribadi yang tangguh dan handal. Pribadi yang mempunyai prestasi yang dapat mengangkat nama baik bangsa.

Secara resmi, olahraga wushu yang bernaung dalam Federasi Wushu Internasional (IWUF) mempertandingkan tiga nomor, yaitu : Taolu (Peragaan bentuk jurus), Tuida (Peragaan pertarungan), Sanshou/Sanda (Pertarungan bebas). Pada pertandingan wushu selain mempertandingakan teknik memainkan senjata juga ada kategori pertarungan Sanshou. Shansou sekilas mirip kickboxing atau thaiboxing, apalagi sama-sama mengenakan celana pendek bersarung tinju. Perbedaannya petarung 
Sanshou memakai kaos dan kepala dilindungi pengaman.

KONI Kabupaten Semarang sebagai organisasi olahraga yang menaungi berbagai macam cabang olahraga dan bertanggung jawab dalam pembinaan prestasi olahraga di Kabupaten Semarang tentunya memiliki pola pembinaan dalam rangka pencapaian target prestasi yang diinginkan. Pola pembinaan yang dipakai KONI sebagai manajemen puncak membawa dampak pada pencapaian target prestasi olahraga Kabupaten Semarang. Pembinaan olahraga untuk mendapatkan atlet berprestasi harus dilakukan dengan rencana yang baik. Dibutuhkan strategi yang efektif, perlu memerhatikan faktor-faktor pendukung dalam mencapai prestasi agar target terpenuhi. Menurut Suharno (2016:6-8) faktor-faktor yang mempengaruhi pencapaian prestasi atlet antara lain : 1. Faktor atlet; 2. Faktor coach; 3. Faktor organisasi yang baik; 4. Faktor tempat/perlengkapan/keuangan; 5. Faktor alam sekitar; 6. Partisipasi pemerintah.

Hal-hal yang memengaruhi pencapaian prestasi atlet harus diperhatikan secara menyeluruh, sehingga KONI Kabupaten Semarang sebagai manajemen puncak harus membuat kebijakan yang tepat dalam memanajemen cabang olahraga dan atlet yang ada di dalamnya. KONI Kabupaten Semarang berupaya untuk memenuhi standar tersebut agar tujuan peningkatan prestasi olahraga dapat tercapai. Pola pembinaan yang dilakukan oleh KONI Jatim menjadi kajian yang menarik, karena pola pembinaan yang digunakan oleh KONI Kabupaten Semarang dapat membawa Kabupaten Semarang mencapai target prestasi yang diinginkan.

Untuk memahami pola pembinaan yang dilaksanakan oleh KONI Kabupaten Semarang maka perlu dilakukan studi di salah satu Cabor yang tergabung dalam program Puslatda. Cabor beladiri Wushu dipilih sebagai objek karena Wushu merupakan salah satu Cabor yang memiliki track record prestasi yang cukup baik. Prestasi yang pernah diraih oleh atlet wushu KONI Kabupaten Semarang adalah dalam kejuaraan Asian Games 20182 Atlet Wushu yang berasal dari Kabupaten Semarang Puja Riyaya dan Yusuf Widiyanto berhasil memperoleh mendali perunggu pada nomor Sanda (tanding) $70 \mathrm{Kg}$ dan Sanda 56 Kg. pada PORPROV tahun 2018 KONI Kabupaten Semarang berhasil menyabet 7 medali emas prestasi ini menjadi salah satu penjulang keberhasilan Kabupaten Semarang yang pada event PORPROV 2016 Kabupaten Semarang peringkat 16 pada PORPROV tahun 2018 Kabupaten Semarang masuk 10 besar diposisi 8 dan masih banyak prestasi Wushu Kabupaten Semarang di event kejuaraan lainya.

Saat ini dunia dikejutkan dengan mewabahnya suatu penyakit yang disebabkan oleh sebuah virus yang bernama corona atau dikenal dengan istilah covid-19. Akibat adanya pandemi covid-19 ini, menyebabkan diterapkannya berbagai kebijakan untuk memutus mata rantai penyebaran virus covid19 tersebut. Social distancing menjadi pilihan berat bagi setiap negara dalam menerapkan kebijakan untuk pencegahan penyebaran covid-19, karena kebijakan ini berdampak negatif terhadap segala aspek kehidupan. 
Pembatasan interaksi sosial masyarakat dapat menghambat laju pertumbuhan dan kemajuan dalam berbagai bidang kehidupan, namun tidak ada pilihan lain, karena cara ini adalah yang paling efektif. Kebijakan Social Distancing berakibat fatal terhadap roda kehidupan manusia, masalah ekonomi yang paling terasa dampaknya, karena hal ini menyentuh berbagai lapisan masyarakat. Tak terkecuali di bidang pembinaan olahraga juga ikut terdampak kebijakan ini. Peralihan kebijakan ini memaksa berbagai pihak, termasuk KONI Kabupaten Semarang untuk mengikuti alur yang sekiranya bisa ditempuh agar pembinaan olahraga prestasi khusunya cabang olahraga beladiri wushu.

Tujuan penelitian ini untuk mendeskripsikan pola pembinaan prestasi olahraga beladiri wushu KONI Kabupaten Semarang di masa pandemi Covid 19.

\section{METODE}

\section{Jenis Penelitian}

Jenis penelitian ini adalah penelitian deskriptif. Nasution (2013: 9) menjelaskan bahwa penelitian kualitatif sangat deskriptif, yaitu mengumpulkan data deskriptif sebanyak mungkin yang dituangkan dalam laporan dan uraian. Nyoman Dantes (2012: 51) mengartikan penelitian deskriptif sebagai penelitian yang berusaha mendeskripsikan suatu fenomena secara sistematis, apa adanya, dilakukan untuk memperoleh informasi saat ini. Sehingga, penelitian ini menyajikan data berupa deskripsi proses pelaksanaan program beserta kendala-kendala yang ditemui dalam rangka pola pembinaan prestasi olahraga beladiri wushu KONI Kabupaten Semarang.

\section{Setting Penelitian}

Penelitian ini dilakukan di KONI Kabupaten Semarang. Penelitian dilaksanakan pada tanggal 11 12 bulan Januari 2021. obyek dalam penelitian ini adalah pola pembinaan prestasi olahraga beladiri wushu di KONI Kabupaten Semarang.

Sumber data dari penelitian ini berasal dari informasi yang terseleksi sesuai dengan fungsi dan kewenangan yang dimiliki. Informasi terdiri dari : (1) Informasi dari 8 atlet tentang pola pembinaan atlet beladiri wushu di KONI Kabupaten Semarang,(2) Informasi dari 2 pelatih tentang kondisi atlet, sarana dan prasarana yang diperlukan, jadwal latihan, dan prestasi yang diraih, dan (3) Informasi dari 2 pengurus KONI tentang monitoring cabang olahraga beladiri wushu di KONI Kabupaten Semarang.

\section{Teknik dan Instrument Pengumpulan Data}

Teknik pengumpulan data dalam penelitian ini mengunakan teknik Triangulasi. Triangulasi pada hakikatnya merupakan pendekatan multimetode yang dilakukan peneliti pada saat mengumpulkan dan menganalisis data. Ide dasarnya adalah bahwa fenomena yang diteliti dapat dipahami dengan baik sehingga diperoleh kebenaran tingkat tinggi jika didekati dari berbagai sudut pandang. Memotret 
fenomena tunggal dari sudut pandang yang berbeda-beda akan memungkinkan diperoleh tingkat kebenaran yang handal. Karena itu, triangulasi ialah usaha mengecek kebenaran data atau informasi yang diperoleh peneliti dari berbagai sudut pandang yang berbeda dengan cara mengurangi sebanyak mungkin bias yang terjadi pada saat pengumpulan dan analisis data. (Rahardjo, 2010: 1)

Pengumpulan data mengunakan wawancara, observasi dan dokumentasi, untuk melengkapi dan memperkuat data yang telah diperoleh maka perlu adanya wawancara, observasi dan dokumentasi.

\section{Keabsahan Data}

Untuk mendapatkan keabsahan data yang objektif diperlukan uji keabsahan data. Dalam penelitian ini mengunakan Teknik pemeriksaan keabsahan data yang digunakan dalam penelitian ini adalah teknik Triangulasi.

Triangulasi adalah suatu cara mendapatkan data yang benar-benar absah dengan mengunakan metode ganda. Triangulasi adalah teknik pemeriksaan keabshahan data dengan cara memanfaatkan sesuatu lain diluar data itu sendiri, untuk keperluan pengecekan atau sebagai pembanding terhadap data itu. (Bachtiar S, $2010: 56$ )

Dalam penelitian ini peneliti menggunakan teknik pemeriksaan keabsahan data triangulasi dengan sumber dan triangulasi dengan metode. Dengan teknik triangulasi dengan sumber (pengurus, pelatih, dan atlet), peneliti membandingkan hasil wawancara yang diperoleh dari masing-masing sumber atau informan penelitian sebagai pembanding untuk mengecek kebenaran informasi yang didapatkan. Selain itu peneliti juga melakukan pengecekan derajat kepercayaan melalui teknik triangulasi dengan metode, yaitu dengan melakukan pengecekan hasil penelitian dengan teknik pengumpulan data yang berbeda yakni wawancara, observasi, dan dokumentasi sehingga derajat kepercayaan data dapat valid.

\section{Teknik Analisis Data}

Menurut Sugiyono (2015: 246) langkah-langkah dalam analisis data yaitu reduksi data (display data), penyajian data (display data) dan conclusion drawing/verification.

\section{Reduksi data (reduction data)}

Data yang diperoleh dari lapangan jurnalnya cukup banyak, untuk itu maka perlu di catat secara teliti dan rinci. Seperti telah dikemukakan, semakin lama peneliti ke lapangan, maka jumlah data akan semakin banyak. Kompleks dan rumit. Mereduksi data berarti merangkum, memilih hal-hal yang penting, dicari tema dan polanya.

\section{Penyajian data (display data)}

Penyajian data adalah cara yang dilakukan untuk memudahkan dalam memahami apa yang telah dipahami. Penyajian data bisa dilakukan dalam bentuk uraian singkat, bagan, hubungan antar kategori, flowchart dan sejenisnya. Peneliti akan menggunakan tabel untuk menyajikan data yang 
telah dianalisis.

\section{Conclusion drawing/verification}

Verifikasi dan simpulan adalah mengecek kembali (diverifikasi) pada catatan-catatan yang telah dibuat oleh peneliti dan selanjutnya membuat simpulan-simpulan sementara.Teknik analisis data adalah cara yang digunakan untuk menganalisis data yang diperoleh dari pengumpulan data dan mendapatkan data sesuai dengan tujuan penelitian. Bagian ini berisi sub bagian dari Metode. Penulis dapat menggunakan style heading 2 untuk sub judul. Penulis dapat menggunakan style heading ini untuk di sub judul di bagian lain di dalam manuscript ini.

\section{HASIL DAN PEMBAHASAN}

Bagian ini memuat hasil atau data penelitian, analisis data penelitian, jawaban dari pertanyaaan penelitian, dan analisis terhadap temuan selama penelitian.

\section{Pola Pembinaan Prestasi Olahraga Beladiri Wushu}

Pembinaan prestasi dalam cabang olahraga, dapat dikatakan baik apabila komponen-komponen pembinaan prestasi yang terdiri dari pelatih, atlet, program latihan, latihan, lembaga yang bertanggung jawab, sarana dan prasarana, dan pendanaan berada pada kondisi yang ideal untuk mencapai tujuan pembinaan prestasi yang diharapkan. Sedangkan kegiatan pembinaan dikatakan kurang baik apabila komponen-komponen pembinaan berada pada kondisi sangat terbatas atau kurang ideal sehingga pencapaian tujuan pembinaan prestasi tidak dapat tercapai secara maksimal. Pola pembinaan prestasi olahraga beladiri wushu di KONI Kabupaten Semarang ini telah memenuhi kriteria dan komponen dalam pembinaan prestasi tersebut.

Pembinaan yang selama ini diterapkan di KONI Kabupaten Semarang adalah sistem talent scouting, yang terprogram dan berkesinambungan, didukung faktor penunjang yang memadai. Talent scouting maksudnya proses pemanduan bakat atlet dari mulai tahap perekrutan sampai tahap akhir pelaksanaan pembinaan. Sesuai dengan sistem piramida pembinaan prestasi olahraga yaitu melalui pembibitan, pemanduan bakat, dan pematangan juara.

\section{Pembibitan}

Pembibitan maksudnya upaya yang diterapkan untuk menjaring atlet berbakat dalam olahraga prestasi yang diteliti secara terarah dan intensif melalui orang tua, guru, dan pelatih pada suatu cabang olahraga. Dalam hal ini pembibitan olahraga beladiri wushu yang harus dilakukan sedini mungkin untuk dilanjutkan dengan pembinaan yang intensif.

\section{Pemanduan bakat}

Pemanduan bakat untuk atlet beladiri wushu maksudnya usaha yang dilakukan untuk 
memperkirakan latihan sehingga mencapai prestasi puncak. Ada 2 cara yang bisa dilakukan dalam mengidentifikasi atlet berbakat yaitu seleksi alamiah dan seleksi ilmiah. Identifikasi pemanduan bakat atlet beladiri wushu di KONI Kabupaten Semarang dilakukan oleh tim talent scouting, yang difokuskan pada atlet beladiri wushu usia remaja.

\section{Pembinaan}

Pola pembinaan atlet beladiri wushu diarahkan pada proses latihan yang sesuaidengan kebutuhan peningkatan prestasi atlet, dalam hal ini peran pelatih sangat menentukan keberhasilan atlet. Dalam suatu pembinaan, evaluasi merupakan hal yang sangat penting dan harus dilakukan secara berkala selama proses pembinaan.

\section{Sistem Pelatihan}

Sistem pelatihan pada pola pembinaan prestasi mempunyai tujuan meningkatkan keterampilan prestasi semaksimal mungkin. Tugas utama pelatih beladiri wushu di KONI Kabupaten Semarang adalah membina dan membimbing atlet. Bentuk perkembangan dari sistem latihan harus dapat dibuat model latihan untuk jangka panjang yang diterapkan semua pelatih.

\section{Kualitas Atlet}

Atlet merupakan faktor yang sangat berpengaruh terhadap pencapaian prestasi. Atlet beladiri Wushu KONI Kabupaten Semarang dilihat dari semangat untuk berlatih tinggi, usaha mereka untuk lebih berprestasi cukup baik, dengan kedisiplinan serta motivasi yang besar dari diri mereka serta didukung oleh pihak-pihak terkait, lebih mempermudah atlet untuk mengembangkan bakat serta mewujudkannya ke dalam suatu prestasi yang membanggakan. Pembinaan olahraga beladiri Wushu membawa dampak positif bagi atlet itu sendiri, diantaranya kedisiplinan, tanggung jawab, sifat sportifitas, memupuk kepercayaan diri, dan semangat yang bertambah.

Berdasarkan hasil analisis deskriptif dalam rekapitulasi data hasil penelitian dapat diketahui bahwa variabel kualitas atlet pembinaan beladiri Wushu di KONI Kabupaten Semarang termasuk dalam kriteria baik karena Keinginan untuk menjadi atlet atas inisiatif sendiri,walaupun ada juga dari dorongan dari keluarga. Sedangkan dalam seminggu, atlet melakukan latihan beladiri lebih dari 3 kali dan ada yang lebih. Motivasi terbesar biasanya datang dari pelatih dan keluarga. Kedisiplinan mereka ditunjukkan dengan selalu datang tepat waktu saat latihan. Selalu mengiktui jadwal yang ditentukan oleh pelatih dan mereka merasa tidak terbebani dengan latihan yang mereka kerjakan karena sudah menjadi konsekuensi dari keinginan mereka untuk berprestasi.

\section{Kualitas Pelatih}

Seorang pelatih harus seorang yang benar-benar mengerti dan mempunyai itikad baik dalam memajukan olahraga nasional, tidak ada motivasi karena mencari popularitas. Sukses dan gagalnya seorang atlet di laga pertandingan, sedikit banyak dipengaruhi oleh peran pelatih dalam memotivasi 
atlet tersebut untuk mengikuti dan melaksanakan program latihan dengan sungguh-sungguh dan bertanggung jawab. Untuk itu, pelatih merupakan sosok yang sangat dibutuhkan dalam pencapaian prestasi atlet. Kebanyakan pelatih adalah seorang mantan atlet yang berkecimpung dalam cabang olahraga tersebut, sama halnya dengan pelatih beladiri Wushu di KONI Kabupaten Semarang mereka dahulu juga mantan atlet beladiri Wushu. Dari pengalaman yang dimilikinya dan tentunya pengetahuan yang melengkapi dirinya menjadi modal pelatih profesional.

Pelatih merupakan seseorang yang paling dekat dengan atlet. Keharmonisan diantaranya akan membawa dampak positif bagi tercapainya tujuan bersama. Peran pelatih sebagai penyusun program latihan itu harus tepat, karena kunci utama keberhasilan adalah pada program latihan, apabila dalam penyusunannyan tidak tepat maka akan terjadi stagnasi prestasi. Peran pelatih yang sangat penting diantaranya adalah mengajarkan kedisiplinan berlatih, menciptakan respon positif dan kerjasama antara pelatih dengan atlet, memberikan rasa kepercayaan diri menjadi atlet, mengajarkan rasa tanggung jawab, dan sebagai pendorong semangat, serta mengembangkan atlet dalam peningkatan prestasi.

Berdasarkan hasil analisis deskriptif dalam rekapitulasi data hasil penelitian pada variabel kualitas pelatih beladiri Wushu di KONI Kabupaten Semarang baik, dilihat dari semua pelatih yang memiliki sertifikasi pelatih, serta pengetahuan mereka dalam membina pembinaan atlet beladiri Wushu sangat berpengalaman dan optimal sehingga prestasi yang dihasilkan sangat membanggakan.

\section{Program Latihan}

Dalam suatu pembinaan olahraga dibutuhkan program yang sistematis dalam pencapaian prestasi maksimal. Program latihan yang diberikan merupakan suatu petunjuk akan perkembangan pembinaan yang dilaksanakan demi tercapainya tujuan maksimal. Manfaat program latihan: 1) merupakan pedoman kegiatan terorganisir untuk mencapai prestasi puncak suatu cabang olahraga, 2) untuk menghindari faktor kebetulan dalam mencapai prestasi puncak dalam olahraga, 3) efektif dan efisien dalam pengunaan waktu, dana, tenaga untuk mencapai tujuan, 4) untuk mengetahui hambatanhambatan dengan cepat dan menghindari pemborosan waktu dana dan tenaga, 5) memperjelas arah dan tujuan yang ingin dicapai, dan 6) sebagai alat kontrol terhadap tercapainya sasaran (Tohar, 2014:32).

Berdasarkan hasil analisis deskriptif dalam rekapitulasi data hasil penelitian pada variabel program latihan dapat diketahui bahwa di lihat dari program latihan yang diberikan dalam pembinaan beladiri Wushu di KONI Kabupaten Semarang termasuk dalam kriteria sudah baik. Dilihat dari perencanaan program latihan yang sudah baik, serta evaluasi pelaksanaan program latihan juga sudah baik. 


\section{Mekanisme Organisasi}

Organisasi adalah keseluruhan proses pengelompokan orang-orang, alat-alat, tugas-tugas serta wewenang dan tanggung jawab sedemikian rupa sehingga terdapat suatu institusi yang dapat digerakkan sebagai suatu kesatuan yang utuh dan bulat dalam rangka pencapaian tujuan yang telah ditentukan sebelumnya (Soekardi, 2006). Secara struktural dalam kepengurusan KONI menerapkan manajemen yang obyektif, dan memberikan motivasi kepada pengurus agar nantinya kedisiplinan diutamakan baik dalam disiplin waktu, disiplin dalam pembinaan anggaran dan juga disiplin melatih atlet dalam latihan. Suatu organisasi dapat berjalan dengan baik dan tearah maka para pengurusnya dalam menjalankan tugas sesuai dengan tanggung jawab dan fungsinya masing-masing. Hubungan dengan lembaga lain juga sangat penting untuk perkembangan KONI itu sendiri.

Berdasarkan hasil analisis deskriptif dalam rekapitulasi data hasil penelitian dari 2 orang pengurus variabel organisasi kepengurusan beladiri Wushu di KONI Kabupaten Semarang termasuk dalam kriteria baik, dilihat dari perhatian pengurus kepada atletnya, dan manajemen kepengurusan beladiri Wushu KONI Kabupaten Semarang itu sendiri.

\section{Sarana dan Prasarana}

Pembinaan yang baik juga harus ditunjang dengan tersedianya fasilitas berupa sarana dan prasarana olahraga, karena sarana dan prasarana merupakan faktor pendukung keberhasilan pembinaan olahrga, yang harus tersedia bagi setiap upaya peningkatan prestasi. Menurut (Soepartono, 2000:6) istilah sarana olahraga adalah terjemahan dari "falicities", yaitu sesuatu yang dapat digunakan dan dimanfaatkan dalam pelaksanaan kegiatan olahraga atau pendidikan jasmani. Pada setiap cabang olahraga, sarana yang dipakai memiliki ukuran standar masing-masing. Dalam olahraga beladiri Wushu sarana yang dibutuhkan antara lain: net, bola, dan perlengkapan pemain seperti kostum dan sepatu.

Secara umum prasarana berarti segala sesuatu yang merupakan penunjang terselenggaranya suatu proses (usaha atau pembangunan). Dalam olahraga prasarana didefinisikan sebagai sesuatu yang mempermudah atau memperlancar tugas dan memiliki sifat yang relative permanent. Salah satu sifat tersebut adalah susah dipindahkan (Soepartono, 2000: 5). Prasarana untuk olahraga beladiri Wushu adalah gedung olahraga.

Berdasarkan hasil analisis deskriptif dalam rekapitulasi data hasil penelitian variabel sarana dan prasarana yang dimiliki KONI Kabupaten Semarang menurut atlet termasuk dalam kriteria baik, karena dari responden atlet menyatakan sangat lengkap dilihat dari kelengkapan dan kualitas sarana dan prasarana yang ada. Menurut para pelatih sarana dan prasarana yang dimiliki KONI Kabupaten Semarang termasuk dalam sudah baik dilihat dari kelengkapan dan kualitasnya, maupun model pengadaan sarana dan prasaran itu sendiri, sedangakan menurut pengurus sarana dan prasarana yang dimiliki KONI Kabupaten Semarang termasuk dalam kriteria baik, dilihat dari kelengkapan dan 
kualitas sarana dan prasarana tersebut baik, model pengadaan sarana dan prasarananya.

\section{Pendanaan}

Dalam aktivitas organisasi maka keuangan adalah sebagai bahan bakarnya. Keuangan yang menggerakkan seluruh bagian organ, oleh karenanya maka setiap organisasi haruslah mempunyai dana keuangan. Hampir dapat dipastikan bahwa dalam anggaran dasar dan anggaran organisasi mengenal sumber keuangan berasal dari beberapa kemungkinan, antara lain : 1) Iuran anggota, 2) Bantuan dari Pemerintah atau pihak ketiga, 3) Usaha lain yang sah dan tidak mengikat (Soekardi, 2006). Keuangan ini haruslah dikelola dengan baik demi kelancaran dan tercapainya tujuan organisasi. Tanpa adanya dana maka suatu organisasi tersebut akan lumpuh. Efisiensi penggunaan dana akan menyuburkan aktivitas organisasi. Managemen yang baik dalam pengelolaan dana akan membawa organisasi dalam aktivitas yang sebenarnya.

Berdasarkan hasil analisis deskriptif dalam rekapitulasi data penelitian variabel pendanaan yang dimiliki KONI Kabupaten Semarang untuk pelaksanaan pembinaan prestasi olahraga beladiri Wushu termasuk dalam kriteria baik, karena dari wawancara responden pelatih dan pengurus dilihat dari sumber pendanaan dan cara mengalokasi dana untuk proses pembinaan karena masih adanya sarana dan prasarana yang belum lengkap.

\section{KESIMPULAN}

Berdasarkan hasil penelitian dapat disimpulkan bahwa pola pembinaan prestasi olahraga beladiri wushu di KONI Kabupaten Semarang menggunakan sistem talent scouting maksudnya proses pemanduan bakat atlet dari mulai tahap perekrutan sampai tahap akhir pelaksanaan pembinaan. Sistem ini berjalan dengan baik, telah terprogram, berjenjang, dan berkesinambungan. Hal ini dilihat mulai dari proses perekrutan atlet yang ketat, sarana prasarana dan program latihan sangat menunjang untuk pembinaan atlet sehingga atlet bisa meraih prestasi. Pengurus, pelatih dan atlet selalu berkoordinasi dengan baik. Pelatih memiliki sertifikasi pelatih, serta pengetahuan mereka dalam membina pembinaan beladiri Wushu. Sarana dan prasarana baik dan lengkap untuk melakukan pembinaan prestasi. Program latihan sudah tersusun dan terlaksana dengan baik, serta mendapat dukungan dari berbagai pihak. Oleh karena itu program pembinaan prestasi olahraga beladiri wushu KONI Kabupaten Semarang dapat berjalan dengan lancar.

\section{DAFTAR PUSTAKA}

Danardono. (2012). Program Pembinaan Prestasi Atlet Kota Yogyakarta Pemusatan Latihan Kota Yogyakarta. http://staff.uny.ac.id 
Efi Dian Sofiana dan Tutur Jatmiko. (2016). Perspektif Pembinaan Tim Puslatda Wushu Sanshou Jawa Timur dalam Persiapan Pekan Olahraga Nasional (PON) yang ke-XIX Tahun 2016 di Jawa Barat. Jurnal. Fakultas Ilmu Keolahragaan, Universitas Negeri Surabaya.

Gunawan, Gugun Arief. 2017. Beladiri. Yogyakarta: PT Pustaka Insan Madani.

Huang, C. et al. (2020). Clinical Features of Patients Infected With 2019 Novel Coronavirus in Wuhan, China. Lancet, 395(10223), 497-506. Retrieved from https://bit.ly/368tofb.

Junaidi, Said. (2013). Pembinaan Olahraga Usia Dini. Semarang: Universitas Negeri Semarang.

M. Afif Saiful Ulum, Heny Setyawati, Cahyo Yuwono. (2013). "Pembinaan Olahraga Bela Diri Wushu Di Kota Salatiga Tahun 2013". Journal of Physical Education, Sport, Health and Recreation 2 (10) (2013). http://journal.unnes.ac.id/sju/index.php/peshr.

KONI, (2006). Gerakan Nasional Garuda Emas Pemanduan dan Pembinaan Bakat Usia Dini. Jakarta: KONI.

Ni Putu Ruspata Bhyantari dan I Made Muliarta. (2016). Kapasitas Aerobik Mahasiswa Pemain Wushu Lebih Baik Daripada Mahasiswa Bukan Pemain Wushu di Universitas Udayana. Jurnal Medika. Vol 5. No. 5: 1.

Rothan, H. A., \& Byrareddy, S. N. (2020). The Epidemiology and Pathogenesis of Coronavirus Disease (COVID-19) Outbreak. Journal of Autoimmunity, 109(102433), 1-4. doi:10.1016/j.jaut.2020.102433.

Sari, Puput Sekar. (2014). Manajemen Pembinaan Prestasi Atlet Beladiri Sumatera Selatan. Universitas PGRI Palembang,177-189.

Sepnu Khoirul Iskandar. (2015). Perbedaan Tingkat Kebugaran Jasmani Peserta Ekstrakurikuler Sepakbola Dan Wushu Di SMP Negeri 1 Jogonalan. Skripsi. Yogyakarta: Fakultas Ilmu Keolahragaan Universitas Negeri Yogyakarta.

Sugiyono, (2015). Metode Penelitian Kuantitatif, Kualitatif, dan R \& D. Bandung: ALFABETA Suharno, H.P. (2016). Ilmu Kepelatihan Olahraga. Yogyakarta.

Suratmin, I Wayan Artanayasa, dan Made Budiawan. 2009. "Pola Pembinaan Cabang Olahraga Pelajar dalam Membangun Prestasi Olahraga Bali”. Jurnal. Jurusan Pendidikan Kepelatihan Olahraga, Fakultas Olahraga dan Kesehatan Universitas Pendidikan Ganesha, Singaraja-Bali Undang-undang Rebublik Indonesia nomor 3 Tahun 2005. Sistem Keolahragaan Nasional. Jakarta: CV. Eko Jaya.

Vasconcelos, B. B. \& Del Vecchio, F. B. (2017). Wushu Sanda: Color bias, home advantage and motor acytions analysis in female match's from the 13th World Championships. Revista de Artes Marciales Asiaticas. Vol 12. No. 1: 1-9. 